\title{
Raman characterization of Avocado Sunblotch viroid and its response to external perturbations and self-cleavage
}

Gaston Hui-Bon-Hoa ${ }^{1 *}$, Hussein Kaddour ${ }^{2}$, Jacques Vergne ${ }^{2}$, Sergei G Kruglik ${ }^{3,4}$ and Marie-Christine Maure $2^{2^{*}}$

\begin{abstract}
Background: Viroids are the smallest pathogens of plants. To date the structural and conformational details of the cleavage of Avocado sunblotch viroid (ASBVd) and the catalytic role of $\mathrm{Mg}^{2+}$ ions in efficient self-cleavage are of crucial interest.

Results: We report the first Raman characterization of the structure and activity of ASBVd, for plus and minus viroid strands. Both strands exhibit a typical A-type RNA conformation with an ordered double-helical content and a C3'-endo/anti sugar pucker configuration, although small but specific differences are found in the sugar puckering and base-stacking regions. The ASBVd(-) is shown to self-cleave 3.5 times more actively than $\mathrm{ASBVd}(+)$. Deuteration and temperature increase perturb differently the double-helical content and the phosphodiester conformation, as revealed by corresponding characteristic Raman spectral changes. Our data suggest that the structure rigidity and stability are higher and the $\mathrm{D}_{2} \mathrm{O}$ accessibility to $\mathrm{H}$-bonding network is lower for ASBVd(+) than for ASBVd(-). Remarkably, the $\mathrm{Mg}^{2+}$-activated self-cleavage of the viroid does not induce any significant alterations of the secondary viroid structure, as evidenced from the absence of intensity changes of Raman marker bands that, however exhibit small but noticeable frequency downshifts suggesting several minor changes in phosphodioxy, internal loops and hairpins of the cleaved viroids.
\end{abstract}

Conclusions: Our results demonstrate the sensitivity of Raman spectroscopy in monitoring structural and conformational changes of the viroid and constitute the basis for further studies of its interactions with therapeutic agents and cell membranes.

Keywords: Viroid, RNA conformation, Self-cleavage activity, $D_{2} \mathrm{O}$ perturbation, Temperature unfolding, Raman spectroscopy

\section{Background}

Viroids are the smallest pathogens of plants; they are characterized by a compact rod-like circular RNA $246-$ 475 nucleotides long [1]; they have no envelope, no capsid and they do not code for any protein. Viroids are divided into two families, the Avsunviroidae such as Avocado sunblotch viroid (ASBVd) that all possess a catalytic RNA with a hammerhead ribozyme (HHR) motif responsible for a crucial cleavage step during viroid replication and

\footnotetext{
* Correspondence: gasthui3@yahoo.fr; marie-christine.maurel@upmc.fr 'Unité 779, INSERM, 78 rue du Général Leclerc, 94276 Le Kremlin Bicêtre, France

${ }^{2}$ UMR 7205, Sorbonne Universités, UPMC Univ Paris 6, 4 place Jussieu, F-75005 Paris, France

Full list of author information is available at the end of the article
}

the Pospiviroidae. The 3D structure of an HHR $[2,3]$ is composed of three helical junctions (I, II, III) with a core of invariant nucleotides required for its activity. The HHR motif of about 35 nucleotides contains a well-conserved single strand region including mandatory nucleotides required for efficient catalysis. Metal ions are involved in HHR activity within the cleavage sites $(\mathrm{C}-\mathrm{U}$ and $\mathrm{C}-\mathrm{G})$. Studies of Chrysanthemum chlorotic mottle viroid (CChMVd) showed that RNA sequences peripheral to the ribozyme can enhance self-cleavage activity $[4,5]$. Cleavage of HHR is a transesterification reaction that converts a $5^{\prime}, 3^{\prime}$ diester to a $2^{\prime}, 3^{\prime}$ cyclic phosphate diester via an SN2 mechanism [6]. During replication, (+) and (-) complementary strand sequences of Avsunviroidae are generated through the symmetric rolling circle mechanism

\section{() Biomed Central}


$[7,8]$. The analysis of the ASBVd contents in avocado extracts [9] revealed the presence of RNA of both polarities in multimeric forms, from monomers to octamers for $\operatorname{ASBVd}(+)$ and monomers to dimers for $\operatorname{ASBVd}(-)$. This difference in oligomeric sizes reveals a less efficient in vivo cleavage activity of $\mathrm{ASBVd}(+)$ than of $\operatorname{ASBVd}(-)$ than was observed by in vitro cleavage. The viroid moves within the cell thanks to intrinsic RNA signals but it is also likely that it recruits supporting protein or RNA factors. It has been shown that complexes between viroids and specific tRNAs exist under physiological conditions. The fact that the concentrations of tRNAs and viroids may be sufficiently high in the cell, suggests that these complexes may also be formed in vivo with functional relevance [10]. Because of the diversity of structures and dynamics that participate in viroid trafficking within the cell and between cells, as well as during infectivity, it is of crucial interest to characterize the structural elements involved in viroid processing. The predicted structures of ASBV(-) and (+) strands have been studied experimentally by Navarro and Flores [11,12]. These structural components might represent the driving force necessary for the viroid to penetrate the cell as well as to interact with cell components. Furthermore, structural elements possibly correspond to functional changes during the life cycle of the viroid [11]. On the other hand, the reconstructed sequence of proto-tRNA ${ }^{\text {Gly }}$ was found to have a sequence capable of adopting a hammerhead structure. Additionally, from base-sequence alignments it is suggested that proto-tRNA ${ }^{\text {Gly }}$ was possibly a viroid-like self-cleavable ribozyme with a hammerhead-like motif [13].

Despite the large amount of information regarding the molecular biology of Avsunviroidae [8], to date little is known regarding the structure and conformational aspects of the cleavage of minus and plus ASBVd strands and the catalytic role of $\mathrm{Mg}^{2+}$ in efficient self-cleavage of such viroids $[12,14]$. Raman spectroscopy has a great potential as a sensitive probe of molecular structure, not only of highly concentrated fibrous forms but also of dilute nucleic acid solutions under near-physiological conditions [15]. Vibrational spectra contain a great deal of information about the molecular structure and dynamics of RNA [16,17]. The common goal in such investigations is to establish a reliable correlation between vibrational spectra and specific structural features of RNAs and their biologically important complexes. In particular Raman vibrational modes of the RNA phosphodiester group and base rings are sensitive to the conformation of the RNA backbone $[18,19]$. Libraries of empirically established correlations between Raman spectra and biologically important active nucleotide structures in the A, B and Z forms have been compiled [19-24], although some correlations involving Raman conformation markers of RNA structures are as yet not fully interpretable and are being intensively investigated. It was found that Raman spectra of different types of RNA are rather similar and possess about 30 characteristic lines that arise from the vibrations of the sugar-phosphate backbone of the RNA and bases [25-27]. Bands assignment in Raman spectra of tRNAs for example, is based on the comparison with the spectra of homopolymers of the four regular ribonucleotides (poly $(\mathrm{G})$, poly $(\mathrm{C})$, poly $(\mathrm{A})$ and poly (U)) [23,28-30].

Here we report the first structural characterization of the minus and plus polarities of ASBVd, by Raman spectroscopy with near-infrared laser excitation light at $780 \mathrm{~nm}$. To obtain further information about the dynamics and stability of such viroids, deuteration $\left(\mathrm{D}_{2} \mathrm{O} / \mathrm{H}_{2} \mathrm{O}\right.$ exchange $)$ and thermal unfolding techniques were used, in conjunction with gel electrophoresis study.

\section{Results and discussion}

\section{Raman bands assignment and structural parameters} for ASBVd

Figure 1 presents the Raman spectra of the minus (curve (a)) and plus (curve (b)) strands of ASBVd, in the range 640-1780 $\mathrm{cm}^{-1}$, in aqueous cacodylate buffer, at $20^{\circ} \mathrm{C}$. These spectra consist of many well-resolved lines that can be grouped into five distinct regions.

(I) Low-frequency region between 600 and $850 \mathrm{~cm}^{-1}$ corresponds to vibrations of the nucleotide heterocyclic rings as well as of the phosphodiester backbone. The weak line at $669 \mathrm{~cm}^{-1}$ and the stronger line at $727 \mathrm{~cm}^{-1}$ correspond to breathing vibration of the $(\mathrm{G})$ and $(\mathrm{A})$ purine bases respectively. The characteristic feature in this region is the existence of two strong sharp bands, at $\sim 785 \mathrm{~cm}^{-1}$ and $\sim 813 \mathrm{~cm}^{-1}$. The band at $\sim 785 \mathrm{~cm}^{-1}$ is assigned to ring breathing of pyrimidine $(\mathrm{C}, \mathrm{U})$ bases $[17,24]$, and the band at $\sim 813 \mathrm{~cm}^{-1}$ is attributed to a symmetric stretching vibration $v_{\mathrm{S}(\mathrm{C}-\mathrm{O}-\mathrm{P}-\mathrm{O}-\mathrm{C})}$ of the phosphodiester linkage of the A-form RNA. Both the intensity and frequency of this latter band are sensitive to bond angle deformations of the RNA backbone [17,26,31,32]. In B-DNA, the strong line at $813 \mathrm{~cm}^{-1}$ is transformed into a weak broad shoulder around $835 \mathrm{~cm}^{-1}$, both bands being independent on base composition [33]. Protonation of poly $(\mathrm{rA})$ at $\mathrm{pH} 5$ results in high-frequency shift $813 \rightarrow 824 \mathrm{~cm}^{-1}$ while the phosphodioxy $\left(\mathrm{PO}_{2}^{-}\right.$) band at $1100 \mathrm{~cm}^{-1}$ (see below) is not affected [34]. It is known that ordered polyribonucleotides exhibit a strong Raman line at $813 \mathrm{~cm}^{-1}$, while no line at this frequency is observed in their disordered structures upon thermal denaturation [30]. As the intensities of the bands at $785 \mathrm{~cm}^{-1}$ and $813 \mathrm{~cm}^{-1}$ vary relatively to each other at different RNA configurations, we have defined 


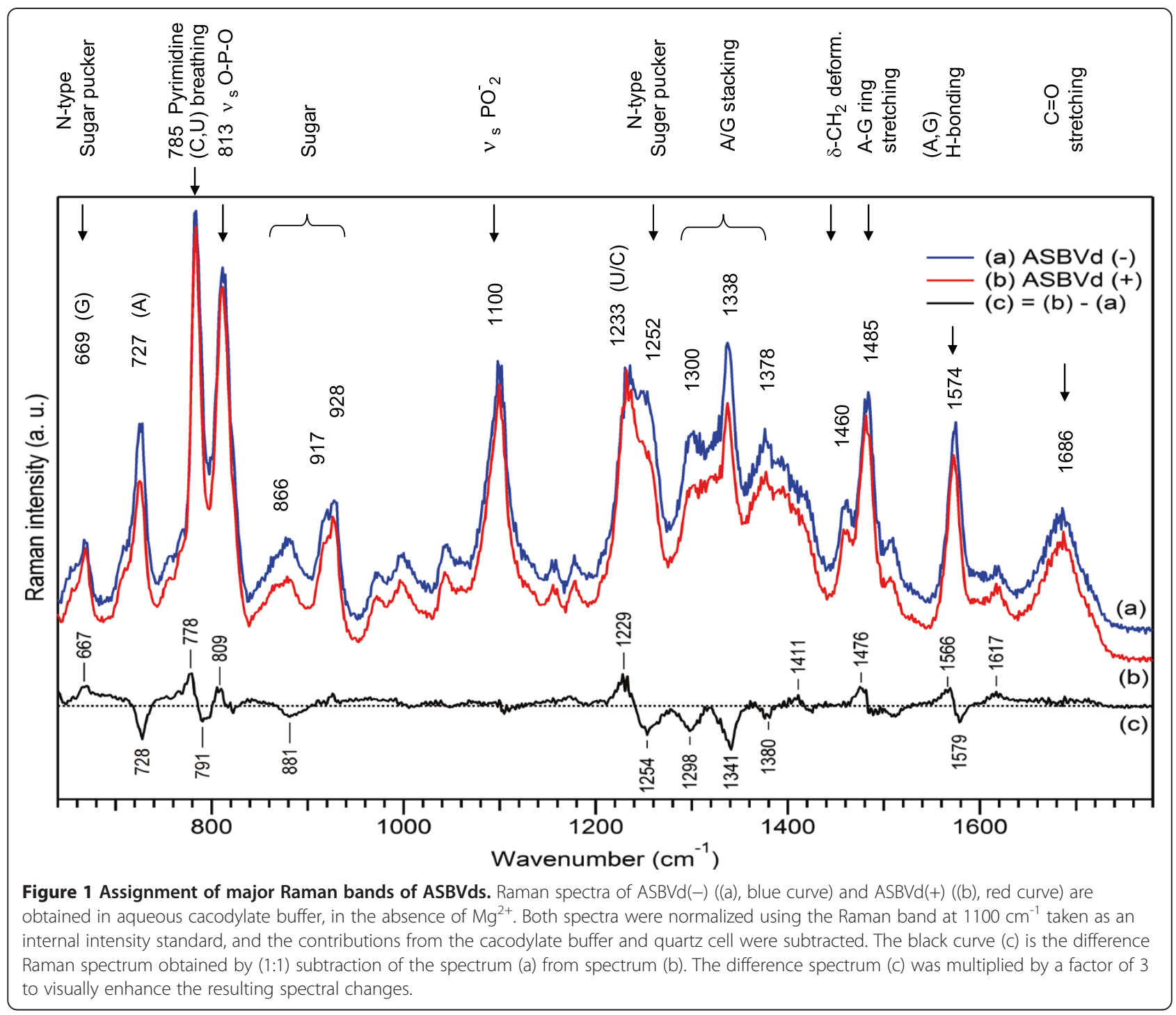

the ratio $\mathrm{r}_{\mathrm{conf}}=\mathrm{I}_{785} / \mathrm{I}_{813}$ to characterize the degree of A-type phosphodiester conformation of the RNA. The spectral overlap between these bands renders the accurate measurement of their intensities difficult; to overcome this problem, we have adopted the method based on peak heights for the estimation of $\mathrm{r}_{\text {conf }}$.

(II) Weaker bands in the region $850-1050 \mathrm{~cm}^{-1}$ originating predominantly from sugars are also sensitive to backbone geometry and secondary structure.

(III) In the range 1050-1150 $\mathrm{cm}^{-1}$, a strong Raman band appears at $\sim 1100 \mathrm{~cm}^{-1}$. This band is assigned to the symmetric stretching vibration $v_{\mathrm{s}}\left(\mathrm{PO}_{2}^{-}\right)$of the phosphodioxy group, sensitive to changes in the electrostatic environment of the phosphate group [35]. At the same time, the $\mathrm{PO}_{2}^{-}$groups essentially constitute an independent oscillator, insofar as they do not couple extensively to the motions of the $\mathrm{C}_{3}$ ' and $\mathrm{C}_{5}$ ' ribose atoms, being largely insensitive to the geometry of sugar-phosphate diester linkages. Therefore, at constant ionic strength, this phosphodioxy stretching vibration is expected to have about the same Raman intensity for all polynucleotides and RNA adopting the same helical structure $[23,36]$. Its intensity depends only on the number of anionic oxygen atoms and serves as a useful internal marker [32], thus normalization on the intensity of this band allows direct comparison between Raman spectra of various nucleic acids. Since the magnitude $\mathrm{I}_{813}$ is directly proportional to the number of phosphodiester linkages in ordered configurations and that of $\mathrm{I}_{1100}$ is independent of such structural factors, we have defined the ratio $\mathrm{r}_{2}=\mathrm{I}_{813} / \mathrm{I}_{1100}$ to characterize the amount of the secondary structure (double helical content) 
$[17,28,32]$. The precision of the determination of the ratio $r_{2}$ is about \pm 0.05 .

(IV) The frequency region $1150-1600 \mathrm{~cm}^{-1}$ contains Raman bands of purine and pyrimidine coupled nucleotide vibrations that are sensitive to ring electronic structures such as base stacking rearrangements, ligation with metal binding, etc. For example, $v_{(\text {pyr }}+$ imidazole) at $1300 \mathrm{~cm}^{-1}$ and $1378 \mathrm{~cm}^{-1}$ are composite vibrations of adenine or guanine ring systems consisting of fused cycles of six-membered pyrimidine and five-membered imidazole (Im) rings, while $v_{(\mathrm{Im})}$ at $1338 \mathrm{~cm}^{-1}$ arises from imidazole ring vibration alone [37]. In our subsequent analysis, the Raman normalized intensity ratio $\mathrm{r}_{\text {stack }}=\left(\mathrm{I}_{1300}+\mathrm{I}_{1378}\right) / \mathrm{I}_{1338}$ was used to characterize base-base stacking interactions. Indeed, in the study of short oligo- and polynucleotides, the value of this parameter has been shown to decrease linearly with the logarithm of the concentration of all three (adenine, AMP and ATP) bases [38], so that Raman band intensities decrease (hypochromicity) when base-base stacking interactions occur. Strong Raman bands around $1233 \mathrm{~cm}^{-1}$ are assigned to U/C ring stretching vibrations which change strongly in intensity upon thermal unfolding (hyperchomicity). Strong Raman band at $1252 \mathrm{~cm}^{-1}$ is assigned to the $\mathrm{C}_{3}{ }^{\prime}$-endo/anti (or so-called $\mathrm{N}$-type) sugar pucker conformation. The ribose in the RNA is manifested by a Raman band at about $1460 \mathrm{~cm}^{-1}$ attributed to methylene twisting $v_{\mathrm{t}(\delta-\mathrm{CH} 2) \text {. Other strong }}$ bands, at $1485 \mathrm{~cm}^{-1}$ and $1574 \mathrm{~cm}^{-1}$, are attributed to purine A-G cycle vibrations along the long/short axis and hydrogen bonding of bases $(A, G)[39]$.

(V) The H-bonding region is located at $1600-$ $1760 \mathrm{~cm}^{-1}$ and shows a broad band centered near $1640-1686 \mathrm{~cm}^{-1}$ which is attributed to the carbonyl $\mathrm{C}=\mathrm{O}$ stretching modes of pyrimidines. The intensity and position of this composite band is sensitive to its coupling with the $\mathrm{N}-\mathrm{H}$ deformation mode of the bases and to thermal denaturation or $\mathrm{D}_{2} \mathrm{O}$ perturbation, reflecting alteration of hydrogen bonding states between the exocyclic donor and acceptor groups of the bases [31].

The Raman spectrum of ASBVd(+) (Figure 1(b)) is rather similar to that of ASBVd(-) (Figure 1(a)), except for some small but detectable differences in (i) the pyrimidine base stretching vibration (at $785 \mathrm{~cm}^{-1}$ and $1233 \mathrm{~cm}^{-1}$ ) and purine rings stretching $\left(727 \mathrm{~cm}^{-1}\right.$ and $\left.1485 \mathrm{~cm}^{-1}\right)$, (ii) the sugar-phosphate backbone regions (at $813 \mathrm{~cm}^{-1}$ and $866 \mathrm{~cm}^{-1}$ ), (iii) the base-stacking (at $1300-1380 \mathrm{~cm}^{-1}$ ) and the $\mathrm{H}$-bonding in the double bond region (at 1540$1600 \mathrm{~cm}^{-1}$ ) but not in the phosphodioxy intensity and position. Figure 1(c) presents Raman difference spectrum (multiplied by a factor of 3) obtained by subtracting the spectrum of $\operatorname{ASBVd}(-)$ from that of $\operatorname{ASBVd}(+)$.

\section{Structure and activity of $\operatorname{ASBVd}(-)$ and $\operatorname{ASBVd}(+)$ Double helical content}

From the data of Figure 1(a) we have calculated that the $\mathrm{r}_{2}$ parameter for the $\operatorname{ASBVd}(-)$ viroid is equal to 1.23 , while it is equal to 1.25 in formylmethionyl-tRNA [25] and 1.33 in the ribozyme D5-PL-RNA [12]. For each of the ordered polyribonucleotides listed in Table IIA of Thomas and Hartman [40], the value of $r_{2}$ was found to be constant at 1.64, indicating the conformational similarity of (-C-O-P-O-C-) linkages. In addition the ratio $\mathrm{r}_{2}$ approaches zero in completely disordered structures $[36,41]$. Hence, the ratio $r_{2}$ observed for $\operatorname{ASBVd}(-)$ and model compounds can be converted into the percentage of ordered polyribonucleotide RNAs using the factor 1.64 as a coefficient of division. The estimate of the number of phosphodiester groups in the ordered region of the viroid RNA, obtained using this procedure, is $~ 75 \%$ whereas it is $76 \%$ for formylmethionyl-tRNA and $81 \%$ for the ribozyme D5-PL-RNA [17]. Subtle conformational differences in the structure of the RNA in ASBVd(-), as compared to the ribozyme D5-PL-RNA are interpreted by the existence of a mixture of serial arrangements of doublehelical sections and internal loops.

The double helical content in ASBVd(+) (Figure 1(b)) is equal to $r_{2}=1.28$, leading to the estimation of $\sim 78 \%$ of the RNA nucleosides in ordered configurations. Thus the secondary structure of the RNA in $\operatorname{ASBVd}(+)$ is more structured than that in $\operatorname{ASBVd}(-)$. In addition, the secondary structure differs slightly in the geometry of the purine bases that exhibit a moderate decrease in intensity (about 15\%) at $727 \mathrm{~cm}^{-1}$. Such a difference is presumably due to ring vibrational coupling between purine bases and the riboses. Our results on double helical content are to be compared to those of Thomas et al. [41] that give the values of $95 \%, 85 \%, 87 \%$ for $16 \mathrm{~S}$ rRNA, $23 \mathrm{~S}$ rRNA and R17 RNA respectively. The secondary structures of these RNAs are more ordered and structured than in the case of ASBVd viroid. It is worth noting that the value of $r_{2}$ as determined from Raman intensity measurements is originated in RNA backbone configuration and not in the bases. So it does not depend on the base sequence as well as on G:C content [41].

\section{Phosphodiester conformations}

The conformation of the sugar-phosphodiester group of $\operatorname{ASBVd}(-)$ is characterized by the parameter $r_{\text {conf }}=1.14$. Interestingly, for a canonical A-form RNA, the Raman doublet $785 / 813 \mathrm{~cm}^{-1}$ exhibits typically a higher Raman intensity of the $811-814 \mathrm{~cm}^{-1}$ band as compared to that at $785 \mathrm{~cm}^{-1}$ leading to $r_{\text {conf }}<1$. At the other extreme, for soluble DNA in a "canonical" B conformation, the 
Raman band at $\sim 813 \mathrm{~cm}^{-1}$ transforms into the broad shoulder at $\sim 835 \mathrm{~cm}^{-1}$ leading to $\mathrm{r}_{\text {conf }} \rightarrow \infty$. However, in the presence of low salt and $75 \%$ humidity, the symmetric phosphodiester band at $\sim 813 \mathrm{~cm}^{-1}$ appears in the DNA fiber yielding $r_{\text {conf }}=1$ [17]. The same conformation was found for ribozyme D5-PL-RNA where $r_{\text {conf }}=1.01$ [12]. The difference in the $r_{\text {conf }}$ parameter between $\mathrm{ASBVd}(-)$ and fiber DNA indicates that although both nucleic acids are in the A conformation, they differ in subtle bond-stretching vibrations located in the $-\mathrm{C}-\mathrm{O}-\mathrm{P}-\mathrm{O}-\mathrm{C}-$ networks and possibly also in the ribose ring [17,32]. A big difference in $r_{\text {conf }}$ was found in the structure of formylmethionyl-tRNA [25] where $r_{\text {conf }}=1.6$, although it exhibits similar to ASBVd ordered secondary structure characterized by the parameter $r_{2}$. This result can be interpreted by a difference in the local phosphodiester conformation of the respective A-type structures.

The value $r_{\text {conf }}$ for ASBVd(+) (Figure 1(b)) is the same as for $\operatorname{ASBVd}(-)$. At the same time a slight frequency downshift is observed in the region of the $-\mathrm{C}-\mathrm{O}-\mathrm{P}$ $\mathrm{O}-\mathrm{C}$ - vibrational mode at $813 \mathrm{~cm}^{-1}$ (Figure $1(\mathrm{c})$ ), indicating a slight difference in the rigidity of the phosphodiester backbone of $\operatorname{ASBVd}(+)$. On the contrary, the phosphodioxy stretching mode at $1100 \mathrm{~cm}^{-1}$ in both minus and plus strands of the viroid remains the same, both in intensity and frequency.

\section{Base-pairing and base-stacking}

Normalization of viroid Raman spectra on the intensity of $v_{\mathrm{s}}\left(\mathrm{PO}_{2}^{-}\right)$at $1100 \mathrm{~cm}^{-1}$ permits the characterization of the strength of each base-specific vibrational modes and also of the interactions of various nucleic acids with the medium. In particular, for free $\operatorname{ASBVd}(-)$ in the absence of $\mathrm{Mg}^{2+}$, Figure 1(a) shows that the breathing vibration of adenine produces a rather strong band at $727 \mathrm{~cm}^{-1}$ with a normalized intensity of $\mathrm{I}_{727}=0.7$, while the breathing vibration of guanine at $669 \mathrm{~cm}^{-1}$ exhibits much weaker intensity $\left(\mathrm{I}_{669}=0.3\right)$. The Raman bands resulting from (A-G) ring stretching vibrations at $1485 \mathrm{~cm}^{-1}$ and the $\mathrm{H}$-bonding at $1574 \mathrm{~cm}^{-1}$ are strong markers with increased intensities of 0.9 and 0.7 respectively. The $\mathrm{H}$-bonding in the carbonyl $\mathrm{C}=\mathrm{O}$ stretching region manifests itself in a broad band with a maximum around $1686 \mathrm{~cm}^{-1}$ and with an intensity of 0.5 . In the case of $\operatorname{ASBVd}(+)$ (Figure $1(\mathrm{~b})$ ), there are no appreciable changes in the carbonyl stretching region as compared to $\operatorname{ASBVd}(-)$, while there is a slight frequency downshift at $1574 \mathrm{~cm}^{-1}$, which is the $\mathrm{H}$-bonding marker between $A$ and $G$ bases. On the other hand, the base-stacking mode which contributes importantly to the conformation and stability of the RNA structure is of major interest. The previously defined parameter $r_{\text {stack }}$ shows that for free $\operatorname{ASBVd}(-)$ and $\operatorname{ASBVd}(+)$, it is equal to 1.35 and 1.42 respectively thus indicating a slight decrease in base-base interactions in the $\operatorname{ASBVd}(+)$ structure and emphasizing small but noticeable differences in the conformation of the plus versus the minus strand.

\section{Sugar puckering coupled to $(G, U)$ bases}

As indicated in the previous section, the Raman frequency of the purine $(G)$ base for $\operatorname{ASBVd}(-)$ is located at $669 \mathrm{~cm}^{-1}$ with a weaker intensity than the Raman band of the (A) base located at $727 \mathrm{~cm}^{-1}$. However the frequency and intensity of these bands depend on the local conformation of the nucleotides [42]. Because the glycosidic bond $\left(\mathrm{N}-\mathrm{C}_{1}{ }^{\prime}\right)$ is close to the base moiety, there is appreciable vibrational coupling between the weak stretching vibration of the guanine and the stronger one of the ribose. Thus the parameters of the two Raman bands may vary depending on the geometry of the nucleotide bases ("syn" or "anti" overall rotation geometry with respect to the sugar) [43], and could provide information about the torsional rotations of the glycosyl bonds and their flexibility. In $\operatorname{ASBVd}(+)$, the stretching mode at $727 \mathrm{~cm}^{-1}$ for purine bases exhibits a moderate decrease in intensity (about 15\%) as compared to $\operatorname{ASBVd}(-)$ (Figure 1(c)). This can be interpreted as a difference in the ring vibrational coupling between purine bases and ribose in $\operatorname{ASBVd}(+)$, leading to a small local difference between two viroids in the sugar puckering conformation, and suggesting the existence of a more compact and rigid geometry in the backbone of $\operatorname{ASBVd}(+)$.

Interestingly, the conformational features of the nucleotides involved in RNAs motifs are determined by the sugar pucker structures and the bases rotation geometries. For instance, the hairpins contain conformations of two types, the so-called "N-type" and "S-type" conformations. The "N-type" structure is characterized by Raman marker band around 1252-1254 $\mathrm{cm}^{-1}$ which is assignable to $\mathrm{C}-3$ ' atom of the sugar in "endo" position and the corresponding base in "anti" rotation geometry. The "S-type" conformation exhibits Raman marker band around $1267 \mathrm{~cm}^{-1}$, which is assignable to the $\mathrm{C}-2$ ' atom of the sugar in "endo" position and the base in "anti" rotation geometry. Another Raman marker band located in the low frequency region of guanine nucleoside stretching around $669 \mathrm{~cm}^{-1}$ is assignable to $\mathrm{C}_{3}$ '-endo/anti conformation ("N-type"), while the $\mathrm{C}_{3}$ '-endo/syn orientation of any $\mathrm{G}$ base with respect to its adjacent sugar is characterized by Raman marker located at $1320 \mathrm{~cm}^{-1}$ [43]. In our case the Raman spectrum of free $\operatorname{ASBVd}(-)$ in Figure 1(a) shows the presence of a strong band at $1252 \mathrm{~cm}^{-1}\left(\mathrm{I}_{1252}=0.84\right)$ and a weaker band at $669 \mathrm{~cm}^{-1}$ $\left(\mathrm{I}_{669}=0.3\right)$, both bands being assignable to nucleosides in $\mathrm{C}_{3}$ '-endo/anti conformations. The same vibrational stretching bands are also observed in $\operatorname{ASBVd}(+)$ (Figure 1(b)) with only slightly different intensities $\left(\mathrm{I}_{1252}^{+}=0.79\right.$ and 
$\left.I_{669}^{+}=0.39\right)$. This result suggests that in both minus and plus strands of ASBVd, all sugars adopt the N-type conformation of the sugar puckers. Indeed, for both types of ASBVd, neither Raman marker at $1267 \mathrm{~cm}^{-1}$ nor at $1320 \mathrm{~cm}^{-1}$ were observed in our study.

\section{In vitro activity}

Controls of the self-cleavage activity of $\operatorname{ASBVd}(-)$ and $(+)$ have been performed by gel electrophoresis at $45^{\circ} \mathrm{C}$, in two different solvent conditions, $\mathrm{H}_{2} \mathrm{O}$ and $\mathrm{D}_{2} \mathrm{O}$. The cleaved fraction was plotted (Figure 2) versus time and fitted with a single exponential growth equation. Figure 2A reveals that ASBVd(-) is 3.5 times more active in cleaving in $\mathrm{H}_{2} \mathrm{O}$ than in $\mathrm{D}_{2} \mathrm{O}$. The rate constants are respectively 0.032 and $0.009 \mathrm{mn}^{-1}$. After 200 minutes, the cleaved fraction was $\sim 65 \%$ in $\mathrm{H}_{2} \mathrm{O}$ and $\sim 32 \%$ in $\mathrm{D}_{2} \mathrm{O}$. The comparison of the activity profiles (Figure $2 \mathrm{~A}$ versus Figure $2 \mathrm{~B}$ ) shows that $\operatorname{ASBVd}(-)$ is about 3.5 times more active than $\operatorname{ASBVd}(+)$ in $\mathrm{H}_{2} \mathrm{O}$ where the rate is $0.01 \mathrm{mn}^{-1}$. Thus even in the presence of $\mathrm{D}_{2} \mathrm{O}, \operatorname{ASBVd}(-)$ is as active as $\operatorname{ASBVd}(+)$ in $\mathrm{H}_{2} \mathrm{O}$. Besides, the activity of $\mathrm{ASBVd}(+)$ in $\mathrm{D}_{2} \mathrm{O}$ is almost completely quenched (Figure 2B). Such a difference in selfcleavage activity corroborates well with the differences in structural dynamics between $\operatorname{ASBVd}(-)$ and $\operatorname{ASBVd}(+)$ as found from Raman spectra in $\mathrm{D}_{2} \mathrm{O}$ (see below).

Isotope substitution $\left(\mathrm{H}_{2} \mathrm{O} \rightarrow \mathrm{D}_{2} \mathrm{O}\right)$ is usually utilized for elucidation of the mechanism of enzymatic reactions [15]. As an example, Takagi et al. investigated the kinetics of hammerhead ribosyme reaction for $\mathrm{H}_{2} \mathrm{O}$ and $\mathrm{D}_{2} \mathrm{O}$ solvents, in the presence of high concentration of $\mathrm{NH}_{4}^{+}$ and $\mathrm{Li}^{+}$ions [44]. They obtained the higher values of the ratio $\mathrm{k}_{\mathrm{app}}^{\mathrm{H} 2 \mathrm{O}} / \mathrm{k}_{\mathrm{app}}^{\mathrm{D} 20}$ in the former case and concluded that proton transfer occurs only in the $\mathrm{NH}_{4}^{+}$-mediated reaction and not in the $\mathrm{Li}^{+}$-mediated one.
In our case of $\operatorname{ASBVd}(-)$ viroid in the presence of $20 \mathrm{mM} \mathrm{Mg}^{2+}$ ions (Figure 2A), this ratio is equal to 3.5, suggesting a mechanism of acid/base catalysis involving proton transfer.

\section{Effect of physico-chemical perturbations on the viroid structure \\ Solvent deuteration and exchangeable protons}

Raman vibrational spectroscopy of different isotopomers is a useful tool in studies of intermolecular interactions in liquids, as the perturbed spectra in the deuterated environment specifically characterize the mobile hydrogen atoms in the accessible sites of the viroid. In addition, it is currently applied to nucleic acids studies to perturb sensitive frequencies and to identify orientation of phosphodiester linkage and sugar pucker conformations as well as coupling of the double-bond stretching and $\mathrm{N}-\mathrm{H}$ deformation vibrations of the bases $[31,45]$. Figure 3 shows that Raman spectra of deuterated viroid (-) and (+) strands (curves (b)) are substantially different from their non-deuterated analogs (curves (a)). The spectral changes occur in three major frequency regions. Let us first consider the case of ASBVd(-) (Figure 3A).

In the $600-850 \mathrm{~cm}^{-1}$ region, the ring-stretching vibrations of purine and pyrimidine exhibit shifts to lower frequencies. The Raman stretching vibrations of adenine at $727 \mathrm{~cm}^{-1}$ and guanine at $669 \mathrm{~cm}^{-1}$ are downshifted to $717 \mathrm{~cm}^{-1}\left(\Delta v=-11 \mathrm{~cm}^{-1}\right)$ and $662 \mathrm{~cm}^{-1}\left(\Delta v=-7 \mathrm{~cm}^{-1}\right)$ respectively, with moderate intensity changes. This is interpreted in terms of $\mathrm{H}$ to $\mathrm{D}$ atom substitution and the removal of the coupling between the ribose and the purine bases upon deuteration. There was thus more freedom for the base stretching vibrations and for the torsional rotations of the glycosyl bonds, leading to changes
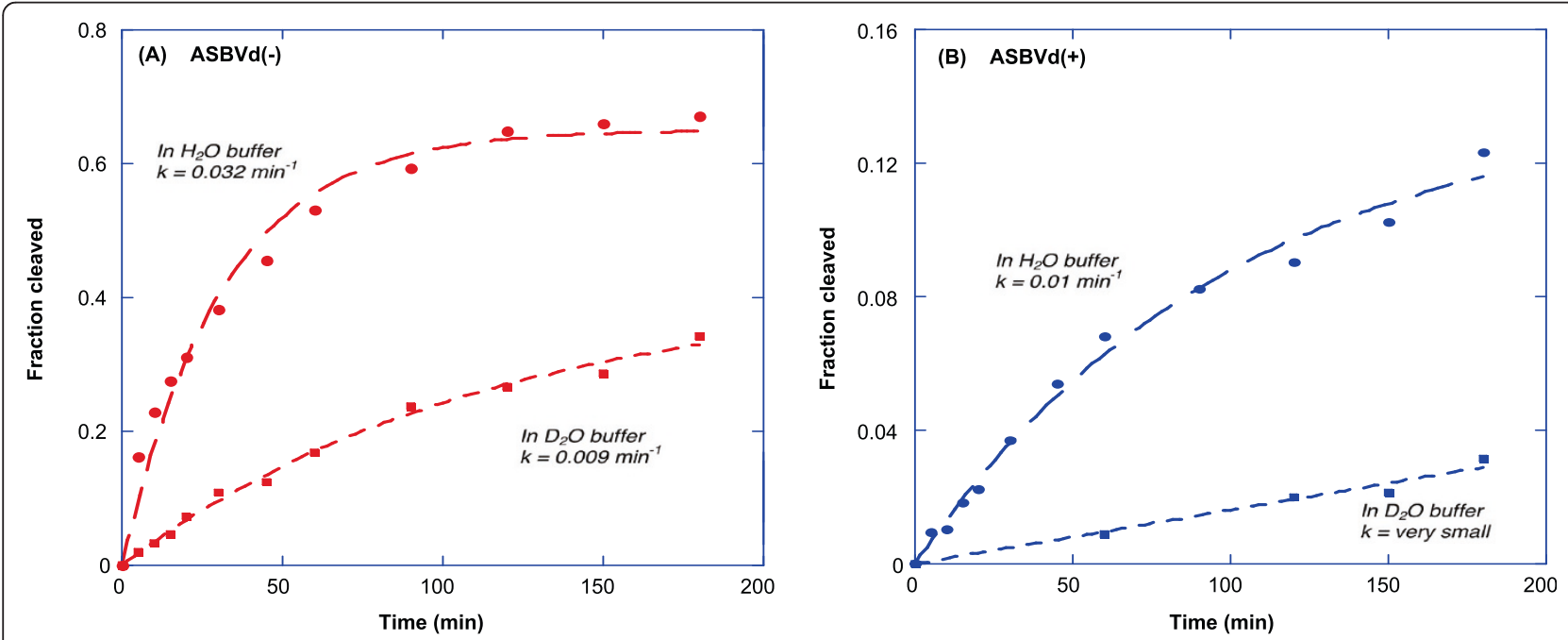

Figure 2 Kinetics of the self-cleavage activity of ASBVds. The kinetic curves of ASBVd minus (panel $\mathbf{A}$ ) and plus (panel B) strands are obtained in cacodylate buffer in $\mathrm{H}_{2} \mathrm{O}$ (circles, long dashes) and in $\mathrm{D}_{2} \mathrm{O}$ (squares, short dashes). 

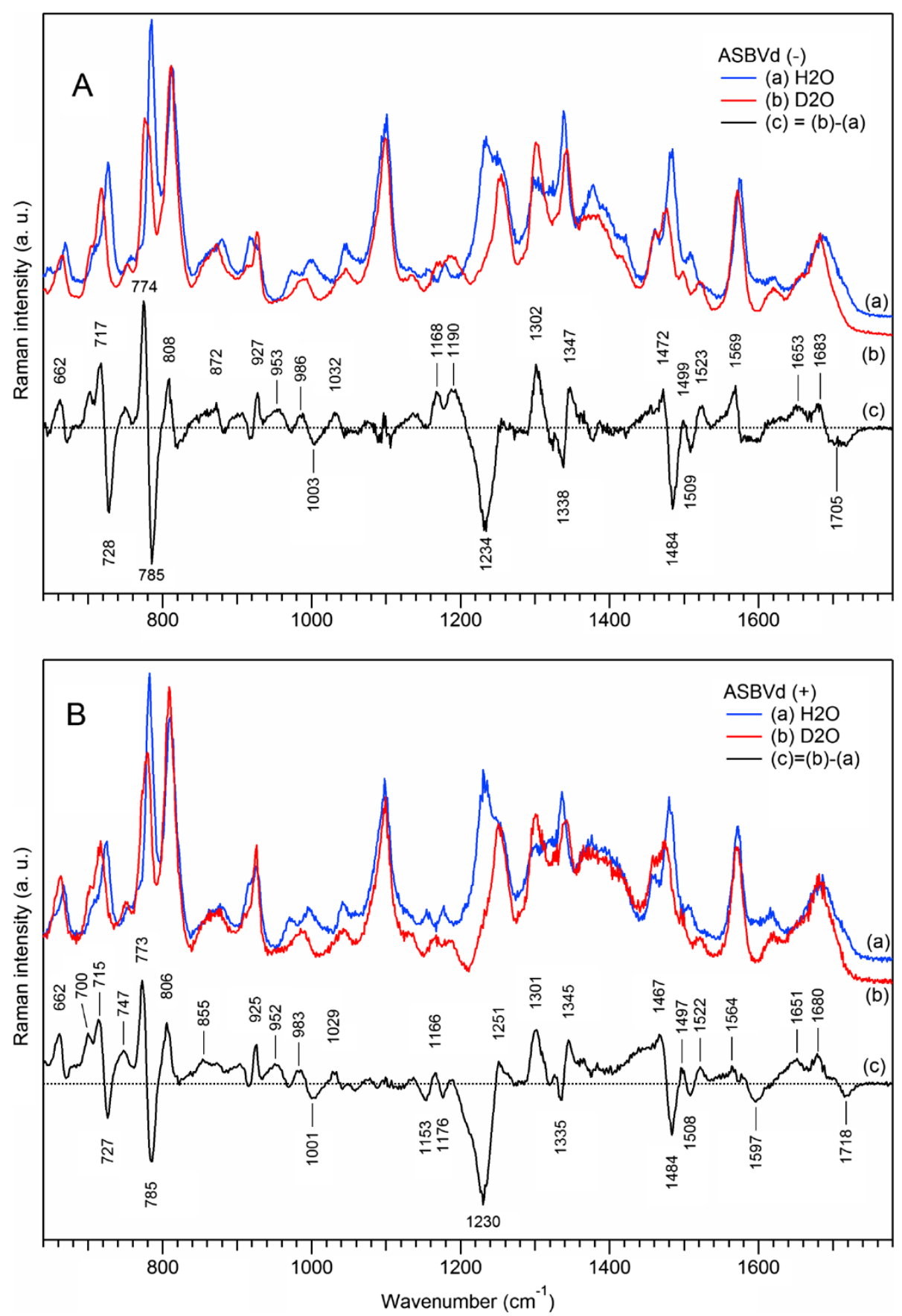

Figure 3 Effect of deuteration on Raman spectra of ASBVds. The Raman spectra of minus (panel A) and plus (panel B) strands of ASBVd are obtained in cacodylate buffer, in the absence of $\mathrm{Mg}^{2+}$. Blue curve (a) correspond to Raman spectra in $\mathrm{H}_{2} \mathrm{O}$; red curve (b) correspond to Raman spectra in $\mathrm{D}_{2} \mathrm{O}$. All spectra were normalized using the Raman band at $1100 \mathrm{~cm}^{-1}$; the contributions from the cacodylate buffer and quartz cell were subtracted. The difference spectrum (c) ( $c=b-a$, black curve) correspond to spectral changes due to $H$ to $D$ atom substitution.

of the backbone conformation. Interestingly, in the presence of $\mathrm{D}_{2} \mathrm{O}$, another A-type structure of the viroid is observed. The position and the shape of the doublet $785 /$ $813 \mathrm{~cm}^{-1}$ changes to $776 / 812 \mathrm{~cm}^{-1}$, with an important intensity decrease of the $(\mathrm{C}, \mathrm{U})$ pyrimidine ring vibrational peak at $776-785 \mathrm{~cm}^{-1}$ and a slight intensity increase of the phosphodiester symmetric peak at $811-813 \mathrm{~cm}^{-1}$. The $\mathrm{r}_{\text {conf }}$ parameter decreases by $25 \%$, from $\mathrm{r}_{\text {conf }}=1.2$ in $\mathrm{H}_{2} \mathrm{O}$ to $\mathrm{r}_{\text {conf }}=0.9$ in $\mathrm{D}_{2} \mathrm{O}$, and the overall amount of double-helical content is increased by $9 \%\left(r_{2}\right.$ changes from 1.28 to 1.40$)$ upon deuteration. Interestingly, the phosphodioxy Raman marker at $\sim 1100 \mathrm{~cm}^{-1}$ is not perturbed. 
In the 1160-1580 $\mathrm{cm}^{-1}$ region, three main changes in the Raman markers are found: i) the strong line of the $\mathrm{U} / \mathrm{C}$ ring stretching vibration located at $1233 \mathrm{~cm}^{-1}$ in water disappears in $\mathrm{D}_{2} \mathrm{O}$ while an intense Raman line at $1302 \mathrm{~cm}^{-1}$ of pyrimidine + imidazole vibration of the adenine ring appears in the spectrum of deuterated $\operatorname{ASBVd}(-)$, indicating that the external "in plane" C-N stretching vibrations of purine and pyrimidine rings are sensitive to $\mathrm{D}_{2} \mathrm{O}$. ii) The stacking parameter $\mathrm{r}_{\text {stack }}$ which is equal to 1.66 in $\mathrm{D}_{2} \mathrm{O}$ as compared to 1.32 in $\mathrm{H}_{2} \mathrm{O}$ increases by about $34 \%$. iii) The band at $\sim 1485 \mathrm{~cm}^{-1}$ assignable to $A / G$ purine ring stretching is also very sensitive to $\mathrm{D}_{2} \mathrm{O}$ perturbation giving a strong negative peak in the difference spectrum. These changes, concomitant with the change of the double helical content, clearly demonstrate that $\mathrm{D}_{2} \mathrm{O}$ perturbs some internal loops, base-base interactions and increases double helical rearrangement in the sugar-phosphate backbone leading to a new conformation and rigidity of the structure.

The broad H-bonding Raman band in the carbonyl region (1640-1740 $\mathrm{cm}^{-1}$ ) becomes more structured: the difference Raman spectrum (Figure 3A(c)) shows peaks at $1683 \mathrm{~cm}^{-1}$ and $1653 \mathrm{~cm}^{-1}$ with a shoulder at $\sim 1621 \mathrm{~cm}^{-1}$. The appearance of these new lines presumably results from the removal of the coupling between the $\mathrm{C}=\mathrm{O}$ double bond stretching and the $\mathrm{N}-\mathrm{H}$ deformation vibrations of the bases upon deuteration. Since the N-D deformation vibrations occur at much lower frequencies around $1200 \mathrm{~cm}^{-1}$, the new spectral pattern in the high-frequency range results solely from the $\mathrm{C}=\mathrm{O}$ stretching of the uracil base: an increase in the number of unpaired uracil residues (peak at $1653 \mathrm{~cm}^{-1}$ ) was observed as compared to the paired uracil residues (peak at $\left.1683 \mathrm{~cm}^{-1}\right)$.

In the case of $\operatorname{ASBVd}(+)$ (Figure 3B), the spectral changes caused by solvent deuteration are generally very similar to those for $\operatorname{ASBVd}(-)$. However, the intensity changes in Raman difference spectrum of $\operatorname{ASBVd}(+)$ (Figure $3 \mathrm{~B}(\mathrm{c})$ ) are weaker than for its minus-strand analogue (Figure $3 \mathrm{~A}(\mathrm{c})$ ), suggesting that the structure of $\operatorname{ASBVd}(+)$ is more rigid, containing less internal loops [11] and is less accessible to $\mathrm{D}_{2} \mathrm{O}$. These results suggest that the exchangeable protons and $\mathrm{H}$-bonding are located mainly in the phosphodiester backbone and in the $(\mathrm{U}, \mathrm{A})$ bases around 1234 and $1484 \mathrm{~cm}^{-1}$ respectively. The base-stacking is also perturbed, but to a lesser extent for $\operatorname{ASBVd}(+)$.

\section{Thermal unfolding}

Application of an unfolding temperature to ASBVd reveals several characteristic spectral features. Figure 4 presents Raman spectra at $20^{\circ} \mathrm{C}$ (curves (a)) and at $65^{\circ} \mathrm{C}$ (curves (b)), together with the difference spectra (curves (c)) that were obtained by (1:1) subtraction of the low-temperature spectrum from the high-temperature one. Note that the intensity of the phosphodioxy stretching vibration around $1100 \mathrm{~cm}^{-1}$ was used as the reference for spectra normalization, prior to spectra subtraction.

As a general conclusion, both strands of ASBVd exhibit temperature-induced spectral changes quite characteristic for polyribonucleotides. The intensity changes of the Raman markers are very similar for ASBVd(-) and $\operatorname{ASBVd}(+)$. More specifically, at $65^{\circ} \mathrm{C}$, there are pronounced changes in the position and intensities of several Raman markers. The strong symmetric (-C-O$\mathrm{P}-\mathrm{O}-\mathrm{C}$-) phosphodiester mode at $813 \mathrm{~cm}^{-1}$ decreases in intensity and is transformed into a broad shoulder at $779 \mathrm{~cm}^{-1}$. Frequency downshift is also observed for the pyrimidine stretching mode at $785 \mathrm{~cm}^{-1}$ which slightly increases in intensity. Other prominent spectral changes involve the frequency downshift of the phosphodioxy symmetric stretching (from $1103 \mathrm{~cm}^{-1}$ to $1087 \mathrm{~cm}^{-1}$ ) and the enhancement of the hyperchromic band around $1226 \mathrm{~cm}^{-1}$ corresponding mainly to a U stretching mode.

The ratio $r_{2}$ decreases from 1.2 to 0.79 , the ratio $r_{\text {conf }}$ increases from 1.2 to 1.8 , and, together with the $813 \mathrm{~cm}^{-1}$ band transformation, indicate the loss of the A-type structure of ASBVd which is characterized by $\sim 48 \%$ ordered double helical content at $65^{\circ} \mathrm{C}$ as compared to $\sim 75 \%$ at $20^{\circ} \mathrm{C}$. Temperature unfolding considerably perturbs the conformational structure of the sugar-phosphodiester backbone for both types of viroid. The bands at $671 \mathrm{~cm}^{-1}$ and 918-928 $\mathrm{cm}^{-1}$ decrease in intensity suggesting some loss of nucleotide conformation and backbone geometry. A hyperchromism of the $1228 \mathrm{~cm}^{-1}$ band and an increase of the $r_{\text {stack }}$ parameter from 1.36 to 1.45 , both indicate the loss of base-stacking and destabilization of the doublehelical structure. A moderate intensity increase in the carbonyl region around $1690 \mathrm{~cm}^{-1}$ reflects the rupture of hydrogen bonds between bases at $65^{\circ} \mathrm{C}$.

We note that the effect of temperature is quite different from that of solvent deuteration (Figure 4 versus Figure 3).

\section{$\mathrm{Mg}^{2+}$ binding before self-cleavage}

It is known that divalent metal cations influence the RNA structure and are potential regulators of ASBVd. Indeed, the $\mathrm{N} 7$ site of $\mathrm{G}$ is an important site for metal cation interactions which bind preferentially to GC rather than to AT regions [46]. Phosphodioxy groups could also be targets. However, the affinity of the interactions with phosphates and specific bases depends on the nature of metal cations (transition metal versus alkaline earth metal) as well as on the type of nucleic acid [44].

Figure 5 shows the effect of adding $20 \mathrm{mM} \mathrm{Mg}^{2+}$ on the structure of $\mathrm{ASBVd}$, at $20^{\circ} \mathrm{C}$. The resulting 

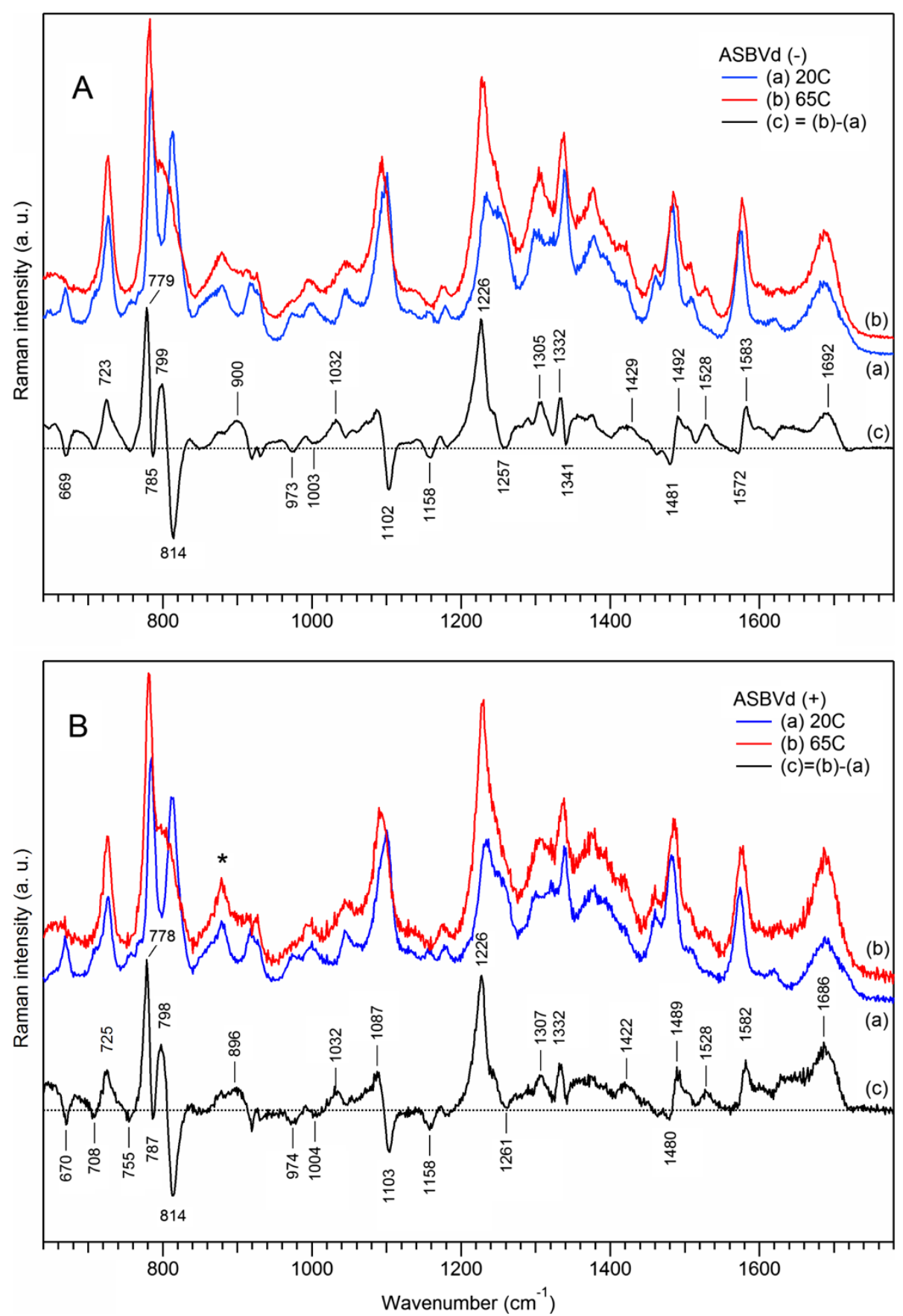

Figure 4 Effect of temperature on Raman spectra of ASBVds. The Raman spectra of minus (panel A) and plus (panel B) strands of ASBVd are obtained in cacodylate buffer, in the absence of $\mathrm{Mg}^{2+}$. Blue curve (a) correspond to Raman spectrum taken at $20^{\circ} \mathrm{C}$; red curve (b) correspond to Raman spectrum taken at $65^{\circ} \mathrm{C}$. All spectra were normalized using the Raman band at $1100 \mathrm{~cm}^{-1}$; the contributions from the cacodylate buffer and quartz cell were subtracted. The difference spectrum (c) ( $c=b-a$, black curve) correspond to spectral changes due to temperature changes.

small but reproducible spectral changes reveal structural perturbations within specific heterocyclic bases. Purine (A) ring stretching vibrations at $727 \mathrm{~cm}^{-1}$ increase by $\sim 7 \%$ in intensity, while there is no or a very small effect in the "N-type" sugar pucker Raman bands ( 4\%). A slight methylene $\delta-\mathrm{CH}_{2}$ deformation change (at $1460 \mathrm{~cm}^{-1}$ ) with a small frequency downshift of $\sim 4 \mathrm{~cm}^{-1}$ is observed. In addition, the intensity increase approaching 6-8\% for $785 \mathrm{~cm}^{-1}$ and $813 \mathrm{~cm}^{-1}$ bands respectively, with no changes of the $r_{\text {conf }}=1.14$ and $r_{\text {stack }}=1.4$ parameters 

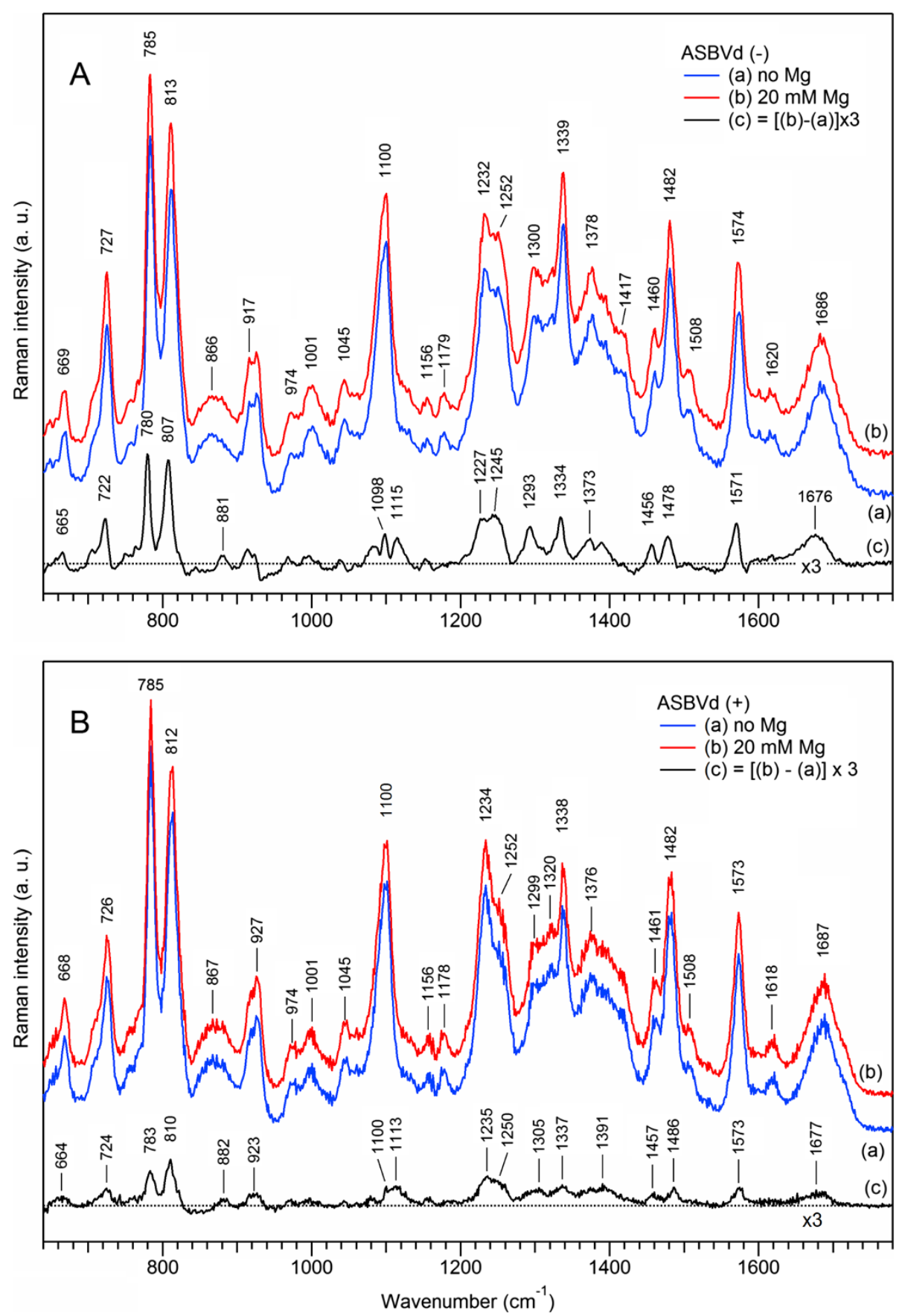

Figure 5 Effect of $\mathbf{M g}^{2+}$ binding on Raman spectra of ASBVds. The Raman spectra of the minus (panel A) and plus (panel B) strands of ASBVd are obtained in cacodylate buffer. Blue curve (a) correspond to Raman spectrum in the absence of $\mathrm{Mg}^{2+}$; red curve (b) correspond to Raman spectrum in the presence of $20 \mathrm{mM} \mathrm{Mg}^{2+}$. Spectra were not normalized in order to see the effect of $\mathrm{Mg}^{2+}$ on the phosphodioxy band at $1100 \mathrm{~cm}^{-1}$, but the contributions from the cacodylate buffer and quartz cell were subtracted. The difference spectrum (c) $(c=b-a$, black curve) was multiplied by a factor of 3 to visually enhance the resulting spectral changes corresponding to $\mathrm{Mg}^{2+}$ binding at $20^{\circ} \mathrm{C}$.

suggests that there is a small local change in the nucleotide geometry and in the 3 '-endo ribose conformation in $\operatorname{ASBVd}(-)$, with no perturbation of the overall backbone geometry. Note that for $\operatorname{ASBVd}(+)$, the intensity increase is less pronounced, being $\sim 5 \%$. At the same time, the phosphodioxy symmetric stretching band at $1100 \mathrm{~cm}^{-1}$ is slightly perturbed in intensity and position (about 3\%). This effect is presumably due to charge neutralization rather than $\mathrm{Mg}^{2+}$ cation binding to the phosphate. Finally, in the purine base stretching, 
H-bonding and $\mathrm{C}=\mathrm{O}$ double bond regions, located around $1480-1700 \mathrm{~cm}^{-1}$, the intensities of the Raman bands also slightly increase. The results clearly favor a specific $\mathrm{Mg}^{2+}$ cation binding to the heterocyclic bases of the ASBVds and not to the phosphates.

Analogous spectral changes were obtained for $\mathrm{Mg}^{2+}$ binding to $\mathrm{ASBVd}(+)$, although to a smaller extent, about $50 \%$ less, than in the case of ASBVd(-).

It is worth noting that the conformation of magnesiumbound viroid at $20^{\circ} \mathrm{C}$ is not an active one, since the in vitro activity experiments show no self-cleavage kinetics.

\section{$\mathrm{Mg}^{2+}$-induced self-cleavage}

Figure 6 presents Raman spectra of auto-catalytic selfcleaved minus (panel A) and plus (panel B) viroid strands. The experiment was performed as follows. The "before cleavage" sample (curves (a)) was the freshly $\mathrm{Mg}^{2+}$-bound viroids at $20^{\circ} \mathrm{C}$. The "after cleavage" sample (curves (b)) was prepared by incubating the initial native viroid in the presence of $20 \mathrm{mM} \mathrm{Mg}^{2+}$ at $45^{\circ} \mathrm{C}$ for 4 hours and then bringing it back to $20^{\circ} \mathrm{C}$, prior to the Raman experiment, so that both spectra (a) and (b) were recorded at $20^{\circ} \mathrm{C}$. The difference Raman spectra (curves (c)) were obtained by 1:1 subtraction of the "before cleavage" sample from the "after cleavage" sample.

The immediate major result deduced from the analysis of the Raman difference spectra, for both viroid strands, is that the event of the viroid self-cleavage is not followed by strong structural perturbations (weak Raman intensity changes) and hence does not significantly alter the initial viroid structure. Nevertheless, we have observed minor but reproducible Raman band shifts upon $\mathrm{Mg}^{2+}$-induced self-cleavage in the spectrum of Figure 6 as compared to that obtained for $\mathrm{Mg}^{2+}$ binding without cleavage (Figure 5). Frequency downshifts of about $10 \mathrm{~cm}^{-1}$ take place with small intensity changes for the pyrimidine peak at $\sim 784 \mathrm{~cm}^{-1}(6 \%$ in $\operatorname{ASBVd}(-)$ and $3 \%$ in $\operatorname{ASBVd}(+))$, and about $4 \%$ intensity changes for the symmetric phosphodiester stretching vibration at $813 \mathrm{~cm}^{-1}$. The $\mathrm{PO}_{2}^{-}$band around $1100 \mathrm{~cm}^{-1}$ is also downshifted by $\sim 9 \mathrm{~cm}^{-1}$ for both viroid strands, with similar small intensity changes of about $8 \%$. Such frequency downshifts for the "after-cleavage" species are indicative of vibrational energy decrease of the phosphate groups. It is presumably a conformational consequence of self-cleavage ( $C-U$ and $C-G$ ) sites leading to the change from a $5^{\prime}, 3^{\prime}$ phosphate diester to a $2^{\prime}, 3^{\prime}$ cyclic phosphate diester. Note that similar changes have been reported in Raman spectra of a model AMP cyclic compound $[44,47]$. In addition, the self-cleavage reaction perturbs both the frequency and intensity of the A stretching mode at $727 \mathrm{~cm}^{-1}$, as well as those of the sugar stretching mode around $929 \mathrm{~cm}^{-1}$. Furthermore, no difference in the $r_{\text {stack }}$ parameter was observed. All these observations indicate that Raman spectroscopy is sensitive enough to reveal local conformational and torsional changes of the phosphate backbone (-C-O-P-O-C-), sugar puckering and base pairing induced by the cleavage of a single adjacent pair of $(C, U)$ or $(C, G)$ bases.

Finally, viroids of minus and plus strands exhibit very similar frequency shifts (Figure 6A(c) versus Figure 6B(c)), but differ in the amplitudes of spectral changes, being $\sim 50 \%$ less pronounced for $\operatorname{ASBVd}(+)$ than for ASBVd(-). Our result is compatible with the in vitro activity measurements which indicate that about $60 \%$ and $10 \%$ of the RNA is cleaved in $\operatorname{ASBVd}(-)$ and $\operatorname{ASBVd}(+)$ strands respectively. Thus we conclude that structural perturbations due to $\mathrm{Mg}^{2+}$-induced self-cleavage are weaker for $\operatorname{ASBVd}(+)$, presumably because its structure is more rigid than that of $\operatorname{ASBVd}(-)$ and/or because $\operatorname{ASBVd}(+)$ is less active, leading to the reduced amount of the cleaved species.

\section{Conclusions}

The results of the present study emphasize the power of the combined use of Raman structural markers, deuteration and temperature perturbation methods to analyze in detail the Raman spectra of the ASBVd minus and plus strands. The specific Raman markers provide not only qualitative but also quantitative information revealing the dynamic picture of the viroid structure.

Many structural details are obtained revealing that the backbone of ASBVd exhibits the A-type conformation with high double helical content, $\mathrm{C} 3$ '-endo/anti sugar puckers and strong base-stacking. Nevertheless small specific differences are detected between the minus and plus viroid strands. The phosphodiester groups in $\operatorname{ASBVd}(+)$ are more rigid than in $\operatorname{ASBVd}(-)$, with slight differences in base-base interactions and ring vibrational coupling between purine bases and the riboses leading to local differences in the sugar puckering conformation. $\operatorname{ASBVd}(+)$ is shown to self-cleave 3.5 times less actively than $\operatorname{ASBVd}(-)$ (Figure 2).

The $\mathrm{D}_{2} \mathrm{O}$ perturbation experiments show that the changes in the ASBVd(-) and (+) spectra are more pronounced than in the case of the self-cleavage reaction. Another A-type conformation of the RNA is observed where $\mathrm{r}_{\text {conf }}$ decreases from 1.2 in $\mathrm{H}_{2} \mathrm{O}$ to 0.9 in $\mathrm{D}_{2} \mathrm{O}$ and where the frequencies of the doublet $\left(785 \mathrm{~cm}^{-1}\right.$ and $\left.813 \mathrm{~cm}^{-1}\right)$ downshift respectively to $11 \mathrm{~cm}^{-1}$ and $5 \mathrm{~cm}^{-1}$. In addition the increase of base-stacking ratio $\left(\mathrm{r}_{\text {stack }}\right)$ clearly demonstrates that deuteration leads to a conformational change of the ribose-phosphate backbone and that the RNA structure is more rigid in $\operatorname{ASBVd}(+)$ than in $\operatorname{ASBVd}(-)$. Raman difference spectroscopy is shown to be a very sensitive technique to reveal small conformational perturbations upon solvent replacement, in the internal loops as well as in the hairpins of RNA dynamic structures. 

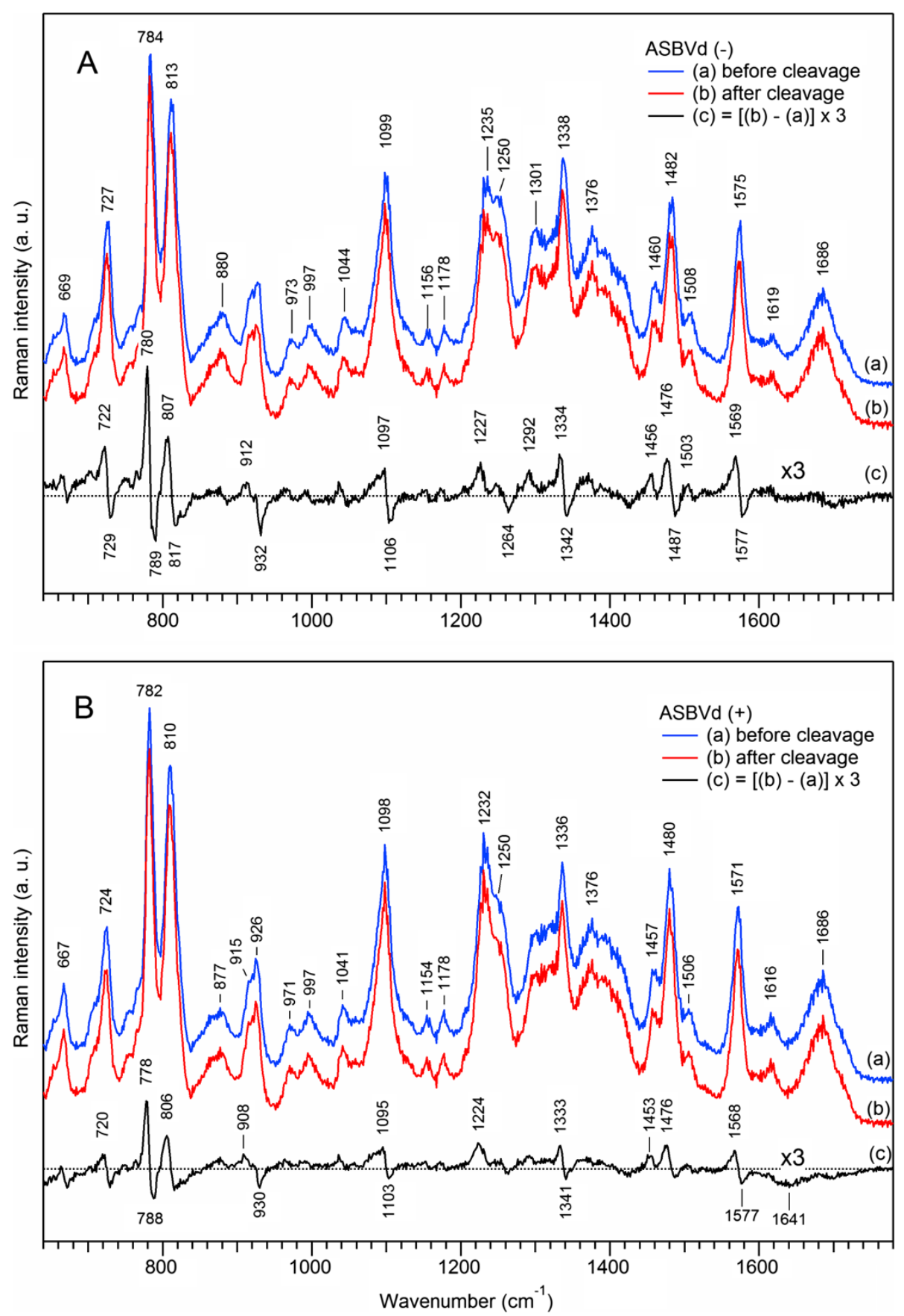

Figure 6 Effect of $\mathbf{M g}^{2+}$-induced self-cleavage on Raman spectra of ASBVds. The Raman spectra of the minus (panel $\mathbf{A}$ ) and plus (panel B) strands of ASBVd are obtained in cacodylate buffer, in the presence of $20 \mathrm{mM} \mathrm{Mg}^{2+}$. Blue curve (a) correspond to Raman spectrum taken before cleavage; red curve (b) correspond to Raman spectrum taken after cleavage (see text for details). All spectra were normalized using the Raman band at $1100 \mathrm{~cm}^{-1}$; the contributions from the cacodylate buffer and quartz cell were subtracted. The difference spectrum (c) (c=b-a, black curve) was multiplied by a factor of 3 to visually enhance the resulting spectral changes corresponding to $\mathrm{Mg}^{2+}$ induced self-cleavage.

Unfolding temperature at $65^{\circ} \mathrm{C}$ mainly perturbs the phosphodiester conformations as seen in the changes of the $785 / 813 \mathrm{~cm}^{-1}$ doublet and of the phosphodioxy band at $1100 \mathrm{~cm}^{-1}$. The perturbed spectra indicate mainly a disruption of the A-type structure of ASBVd through the double helical to random coil conformation transitions and the loss of stacking between bases (about 21\%). No change in the sugar puckers but strong hydration and bond formation affecting the phosphodioxy charges are revealed from the downshift of phosphodioxy symmetric 
stretching at $1100 \mathrm{~cm}^{-1}$. The ASBVd(+) shows the same spectra perturbations but to a lesser extent and it is demonstrated that the positive strand is more stable than the negative strand.

Binding of $\mathrm{Mg}^{2+}$ to both viroid strands leads to small increases of the Raman intensities in the phosphodiester backbone modes with no changes in base-stacking and a moderate increase in $\mathrm{H}$-bonding. The small increase in $\mathrm{H}$-bonding is not due to increase in ionic strength of the magnesium cations, but rather due to magnesium effect on the specific bases of ASBVds (see Methods, Viroid preparation). The spectral changes are weaker for $\operatorname{ASBVd}(+)$ as compared to ASBVd(-). Magnesium binding to ASBVds at room temperature does not give rise to an active conformation. The active species is produced usually at a temperature of $45^{\circ} \mathrm{C}$.

Self-cleavage of the RNA in ASBVd viroids is not followed by strong structural perturbations and hence does not significantly alter the initial viroid structure. However we were able to detect minor but readily measurable spectral changes that are different from that of simple $\mathrm{Mg}^{2+}$ binding. Viroid self-cleavage leads to very small perturbations in Raman intensities, but rather noticeable frequency downshifts of some Raman markers. The N-type sugar puckers decrease by $~ 5 \%$. Such types of changes suggest that a local cleavage in a single adjacent pair of $(\mathrm{C}, \mathrm{U})$ bases could induce local conformational and torsional changes of the phosphate (-C-O-P-O-C-) backbone. No change in double helical content was detected. The spectral changes were weaker in the case of $\operatorname{ASBVd}(+)$, presumably because the structure of the positive strand is more rigid than that of the negative strand.

Finally spectral changes in Raman difference spectra due to external perturbations and self-cleavage could be plausibly associated with various structural changes in double helices, internal loops, hairpins and three-way junction in the two ASBVd structures as predicted in Ref. [11].

\section{Methods}

\section{Plasmid construct}

Plasmid $p B m A S B V d$ was constructed by cloning the monomer ASBVd sequence into the PKS plasmid, restricted by the EcoR1 and BamH1 enzymes, and the monomer sequence was extracted from the plasmid pBdASBVd containing a dimeric viroid cDNA [45].

\section{Viroid preparation}

ASBVd (247 nt RNA single chains plus two guanylic residues added at the $5^{\prime}$ end for efficient transcription) were prepared by in vitro transcription. DNA templates used for transcription to synthesize the $(-)$ and $(+)$ ASBVd, were PCR amplified products obtained using respectively the oligonucleotides sense $5^{\prime}$-TAATAC GACTCACTATAGGAAGAGATTGAAGACGAGTG-3' containing the $T 7$ promoter (italic font), and antisense 5' -GATCACTTCGTCTCTTCAGG-3', or the oligonucleotides sense 5'-AAGAGATTGAAGAC GAGTG-3' and antisense 5' TAATACGACTCACTATAGGGATCA CTTCGTCTCT TCAGG-3' containing the $T 7$ promoter (italic font) as primers in the presence of the $p B m A S B V d$ plasmid. The recovered cDNAs were precipitated with ethanol, and the resulting pellets were dissolved in water. The transcription reactions performed by the T7 RNA polymerase were carried out overnight at $37^{\circ} \mathrm{C}$ in a final volume of $5 \mathrm{ml}$ containing transcription buffer, each rNTP and RNase inhibitor (Fermentas). The transcriptions were stopped by treatment with RNase-free DNase I (Fermentas), for $30 \mathrm{~min}$ at $37^{\circ} \mathrm{C}$, to degrade the DNA templates. The RNAs were precipitated with ethanol and resuspended in water, $0.05 \%$ xylene cyanol, and $50 \%$ deionized formamide. The resulting mixture was denatured for $2 \mathrm{~min}$ at $65^{\circ} \mathrm{C}$ prior to fractionation by denaturing (7 M urea), 10\% polyacrylamide gel electrophoresis (PAGE, 19:1 ratio of acrylamide/bisacrylamide) using TBE buffer. Transcripts were detected by UV shadowing and the bands corresponding to full-length viroids of both polarities were excised, the RNA eluted overnight in $300 \mathrm{mM}$ sodium acetate, $\mathrm{pH}$ 5.2, filtered through $0.22 \mu \mathrm{M}$ filters, ethanol precipitated and dried. After dissolving in ultrapure water, the RNA concentrations were determined by UV absorbance (NanoVue GE Healthcare) and the samples were stored at $-20^{\circ} \mathrm{C}$.

For Raman experiments, $800 \mu \mathrm{g}$ of dry RNA were suspended in $10 \mu \mathrm{l}$ of water and denatured at $95^{\circ} \mathrm{C}$ for $45 \mathrm{sec}$ and then slowly $\left(3^{\circ} \mathrm{C} / \mathrm{min}\right)$ renatured by cooling to $20^{\circ} \mathrm{C}$. Salts and buffer were adjusted to the experimental conditions in a total volume of $10-20 \mu \mathrm{L}$. The final viroid concentration in the sample cell varied between 0.63 and $1 \mathrm{mM}$. The standard aqueous cacodylate buffer used in Raman experiments (if not indicated otherwise) was the following: $\mathrm{H}_{2} \mathrm{O}, 20 \mathrm{mM}$ sodium cacodylate $\mathrm{pH} 7.2,150 \mathrm{mM} \mathrm{KCl}$, without $\mathrm{Mg}^{2+}$, at $20^{\circ} \mathrm{C}$. The total ionic strength of the buffer is $I_{\text {buffer }}=170 \mathrm{mM}$, while that of added $20 \mathrm{mM} \mathrm{Mg}^{2+}$ is $\mathrm{I}_{\mathrm{Mg} 2+}=60 \mathrm{mM}$. The addition of $20 \mathrm{mM} \mathrm{Mg}^{2+}$ in the solution does not change the $\mathrm{pH}$ of the cacodylate buffer. The standard deuterated aqueous cacodylate buffer was the following: $\mathrm{D}_{2} \mathrm{O}$, $20 \mathrm{mM}$ sodium cacodylate $\mathrm{pH} 6.8,150 \mathrm{mM} \mathrm{KCl}$, no $\mathrm{Mg}^{2+}$, at $20^{\circ} \mathrm{C}$. The sample cell was thermostated within $\pm 1^{\circ} \mathrm{C}$. For measurements at elevated temperatures, a thin layer of oil was gently poured on top of the sample solution, to prevent evaporation.

\section{Gel electrophoresis experiments}

Kinetics of the viroid cleavage was followed at $45^{\circ} \mathrm{C}$ in $50 \mathrm{mM}$ cacodylate buffer $\mathrm{pH} 7.2$ in the presence of 
$150 \mathrm{mM} \mathrm{KCl}$ and $20 \mathrm{mM} \mathrm{Mg}^{2+}$. Aliquots were removed from the incubating viroid samples at various times and quenched in one volume of stop solution (7 M urea, $50 \mathrm{mM}$ EDTA, pH 7.5 and $0.01 \%$ xylene cyanol). Each aliquot was then loaded onto a denaturing gel (6\% SDSPAGE) to determine the fraction of the cleaved product. The total experiment time was $\sim 3$ hours.

\section{Raman experiments}

Raman spectra of viroids were recorded using a homebuilt near-infrared (NIR) Raman setup [48]. Briefly, the excitation light at $780 \mathrm{~nm}$ was provided by continuouswave Ti:Sapphire laser (Spectra Physics, model 3900S) pumped by an argon-ion laser (Spectra Physics Stabilite 2017). Laser light was focused into the specifically designed quartz sample cell (external dimensions $10 \times 10 \times 40 \mathrm{~mm}$, internal dimensions $2 \times 2 \times 35 \mathrm{~mm}$ ) filled with viroid solution $(10-20 \mu \mathrm{L})$ by an infinity-corrected long working distance objective (Olympus MA10, M=10X, NA =0.25). Excitation power was attenuated to $\sim 300 \mathrm{~mW}$ in the sample cell. The same objective was used to collect the Raman signal in a backscattering geometry and to deliver it onto the spectrograph (Acton SpectraPro 2500i) coupled with deepdepletion back-illuminated NIR CCD (Princeton Instruments SPEC-10 400BR/LN). The Raman light was focused on the spectrograph entrance (slit width $30 \mu \mathrm{m}$ ) by an achromatic lens with $\mathrm{f}=75 \mathrm{~mm}$. The Raman signal was separated from the laser light by two Semrock RazorEdge long pass filters (grade U). One filter, with $\lambda_{\text {laser }}=780 \mathrm{~nm}$, was placed perpendicularly to the optical beam just before the focusing lens; another one, with $\lambda_{\text {laser }}=830 \mathrm{~nm}$, was used as a dichroic beamsplitter at an angle of incidence of $45^{\circ}$ : it reflected laser light at $780 \mathrm{~nm}$ and transmitted all the wavelengths longer than $785 \mathrm{~nm}$. Raman spectra were acquired with the WinSpec software; further data treatment was performed using Igor Pro for Windows software. To obtain the viroid Raman spectrum, the contributions from the PBS and quartz cell were subtracted from the recorded spectrum, normalized on the water bending band around $1640 \mathrm{~cm}^{-1}$. Spectral resolution of Raman experiments was $\sim 5 \mathrm{~cm}^{-1}$; frequency calibration was performed using Raman lines of toluene with absolute accuracy $\pm 2 \mathrm{~cm}^{-1}$ and relative frequency position accuracy better than $\pm 1 \mathrm{~cm}^{-1}$. The total accumulation time for one Raman spectrum was 10 to $30 \mathrm{~min}$ depending on the sample studied.

\section{Competing interests}

The authors declare that they have no competing interests.

\section{Authors' contributions}

GHBH, SGK and MCM planned, conceptualized the study and wrote the manuscript. HK and JV purified the viroids and performed the in vitro activity measurements. HK and SGK ran Raman experiments. SGK and GHBH performed Raman data treatment and analysis. All authors read and approved the final manuscript.

\section{Acknowledgements}

H. Kaddour was recipient of a fellowship from the Centre National de la Recherche Scientifique (CNRS). This study was supported by the University Paris 6, the CNRS (grant PID EPOV), and the Centre National d'Etudes Spatiales. We are grateful to Professor Pierre-Yves Turpin for critical and helpful comments and to Anne-Lise Haenni for careful reading of the manuscript.

\section{Author details}

'Unité 779, INSERM, 78 rue du Général Leclerc, 94276 Le Kremlin Bicêtre, France. ${ }^{2}$ UMR 7205, Sorbonne Universités, UPMC Univ Paris 6, 4 place Jussieu, F-75005 Paris, France. ${ }^{3}$ Laboratoire Jean Perrin (UMR 8237), Sorbonne Universités, UPMC Univ Paris 6, 4 place Jussieu, F-75005 Paris, France. ${ }^{4}$ Laboratoire Jean Perrin (UMR 8237), CNRS, 4 place Jussieu, F-75005 Paris, France.

Received: 18 July 2013 Accepted: 10 February 2014

Published: 21 March 2014

\section{References}

1. Rocheleau L, Pelchat M: The subviral RNA database: a toolbox for viroids, the hepatitis delta virus and satellite RNAs research. BMC Microbiol 2006, 6:24.

2. Scott WG, Finch JT, Klug A: The crystal structure of an all-RNA hammerhead ribozyme - a proposed mechanism for RNA catalytic cleavage. Cell 1995, 81:991-1002.

3. Scott WG, Murray JB, Arnold JRP, Stoddard BL, Klug A: Capturing the structure of a catalytic RNA intermediate: the hammerhead ribozyme. Science 1996, 274:2065-2069.

4. Khvorova A, Lescoute A, Westhof E, Jayasena SD: Sequence elements outside the hammerhead ribozyme catalytic core enable intracellular activity. Nat Struct Biol 2003, 10:708-712.

5. Kaddour $H$, Vergne J, Hervé G, Maurel M-C: High-pressure analysis of a hammerhead ribozyme from Chrysanthemum chlorotic mottle viroid reveals two different populations of self-cleaving molecule. FEBS J 2011, 278:3739-3747.

6. Chen JH, Yajima R, Chadalavada DM, Chase E, Bevilacqua PC, Golden BL: A 1.9 angstrom crystal structure of the HDV ribozyme precleavage suggests both Lewis acid and general acid mechanisms contribute to phosphodiester cleavage. Biochemistry 2010, 49:6508-6518.

7. Daros JA, Marcos JF, Hernandez C, Flores R: Replication of avocado sunblotch viroid - evidence for a symmetrical pathway with 2 rolling circles and hammerhead ribozyme processing. Proc Natl Acad Sci U S A 1994, 91:12813-12817.

8. Gora-Sochacka A: Viroids: unusual small pathogenic RNAs. Acta Biochim Pol 2004, 51:587-607.

9. Hutchins $C J$, Keese P, Visvader JE, Rathjen PD, McInnes JL, Symons RH: Comparison of multimeric plus and minus forms of viroids and virusoids. Plant Mol Biol 1985, 4:293-304.

10. Wild U, Ramm K, Sanger HL, Riesner D: Loops in viroids - accessibility to transfer-RNA anticodon binding. Eur J Biochem 1980, 103:227-235.

11. Ding B, Itaya A: Viroid: A useful model for studying the basic principles of infection and RNA biology. Mol Plant Microbe Interact 2007, 20:7-20.

12. Chen Y, Eldho NV, Dayie TK, Carey PR: Probing adenine rings and backbone linkages using base specific isotope-edited Raman spectroscopy: application to group II intron ribozyme domain V. Biochemistry 2010, 49:3427-3435.

13. Ohnishi K, Ohshima M, Furuichi N: Evolution from possible primitive tRNAviroids to early poly-tRNA-derived mRNAs: a new approach from the poly-tRNA theory. Genome Inform 2005, 16:94-103.

14. Gong B, Chen JH, Bevilacqua PC, Golden BL, Carey PR: Competition between $\mathrm{Co}(\mathrm{NH}(3))(6)(3+)$ and Inner Sphere $\mathrm{Mg}(2+)$ lons in the HDV Ribozyme. Biochemistry 2009, 48:11961-11970.

15. Wartell RM, Harrell JT: Characteristics and variations of B-type DNA conformations in solution - a quantitative analysis of Raman band intensities of 8 DNAs. Biochemistry 1986, 25:2664-2671.

16. Fanconi B, Tomlinso B, Nafie LA, Small W, Peticolas WL: Polarized laser Raman studies of biological polymers. J Chem Phys 1969, 51:3993-4005.

17. Erfurth SC, Kiser EJ, Peticolas WL: Determination of backbone structure of nucleic acids and nucleic-acid oligomers by laser Raman scattering. Proc Natl Acad Sci U S A 1972, 69:938-941. 
18. Small EW, Peticolas WL: Conformational dependence of Raman scattering intensities from polynucleotides. 3. Order-disorder changes in helical structures. Biopolymers 1971, 10:1377-1416.

19. Small EW, Peticolas WL: Conformational dependence of Raman scattering intensities from polynucleotides. Biopolymers 1971, 10:69-88.

20. Thomas GJ, Hartman KA, Medeiros GC: Raman studies of nucleic acids. 6 . Conformational structures of transfer RNA ${ }^{\mathrm{fMet}}$, transfer RNA ${ }^{\mathrm{Val}}$ and transfer RNA ${ }^{2 \text { Phe }}$. Biochim Biophys Acta 1972, 277:71-79.

21. Thomas GJ, Livramento J: Kinetics of hydrogen-deuterium exchange in adenosine 5'-monophosphate, adenosine 3'/5'-monophosphate, and poly(riboadenylic acid) determined by laser Raman spectroscopy. Biochemistry 1975, 14:5210-5218.

22. Thomas GJ, Wang AHJ: Laser Raman spectroscopy of nucleic acids. Nucleic Acids Mol Biol 1988, 2:1-30

23. Nishimura $Y$, Tsuboi M: Local conformations and polymorphism of DNA duplexes as revealed by their Raman spectra. In Advances in Spectroscopy. Vol. 13. Spectroscopy of Biological Systems. Edited by Clark RJ, Hester AE. New York: Wiley; 1986:177-232.

24. Tsuboi M, Benevides JM, Thomas GJ Jr: Raman Tensors and thei application in structural studies of biological systems. P Jpn Acad B - Phys 2009, 85:83-97.

25. Tsuboi M, Takahashi S, Muraishi S, Kajiura T, Nishimura S: Raman spectrum of a transfer RNA. Science 1971, 174:1142-1144.

26. Hobro AJ, Rouhi M, Blanch EW, Conn GL: Raman and Raman optical activity (ROA) analysis of RNA structural motifs in Domain I of the EMCV IRES. Nucleic Acids Res 2007, 35:1169-1177.

27. Hobro AJ, Rouhi M, Conn GL, Blanch EW: Raman and Raman optical activity (ROA) analysis of RNA structural motifs. Vib Spectrosc 2008, 48:37-43.

28. Lord RC, Thomas GJ: Raman spectral studies of nucleic acids and related molecules. I. Ribonucleic acid derivatives. Spectrochim Acta A 1967, 23:2551.

29. Aylward NN, Koenig JL: Laser excited Raman spectra of poly(cytidylic acid). Macromolecules 1970, 3:583.

30. Lafleur L, Rice J, Thomas GJ: Raman studies of nucleic acids. 7. PolyAPolyU and PolyG-PolyC. Biopolymers 1972, 11:2423-2437.

31. Erfurth SC, Peticolas WL: Melting and premelting phenomenon in DNA by laser Raman scattering. Biopolymers 1975, 14:247-264.

32. Brown EB, Peticolas WL: Conformational geometry and vibrational frequencies of nucleic-acid chains. Biopolymers 1975, 14:1259-1271.

33. Thomas GJ, Benevides JM, Prescott B: In Biomolecular Stereodynamics, vol. IV. Edited by Sarma S, Sarma A. NY: Adenine Press Guilderland; 1986:227.

34. Yu NT: Ph. D. Thesis. Cambridge, Massachussets: Department of Chemistry, MIT; 1969:02139 11.

35. Benevides JM, Weiss MA, Thomas GJ: Raman studies of nucleic-acids. 41. Design of the helix-turn helix motif - nonlocal effects of quaternary structure in DNA recognition investigated by laser Raman spectroscopy. Biochemistry 1991, 30:4381-4388.

36. Medeiros GC, Thomas GJ: Raman studies of nucleic acids. 4. Vibrational spectra and associative interactions of aqueous inosine derivatives. Biochim Biophys Acta 1971, 247:449-462.

37. Valdemaras R: Interactions of cyclic AMP and its dibutyryl analogue with model membrane: X-ray diffraction and Raman spectroscopy study using cubic liquid-crystalline phases of monoolein. Biophys Chem 2001, 90:75-87.

38. Weaver $J$, Williams RW: Raman spectroscopic measurement of base stacking in solutions of adenosine, AMP, ATP, and oligoadenylates. Biochemistry 1988, 27:8899-8903.

39. Fujimoto N, Toyama A, Takeuchi H: Effects of hydrogen bonding on the UV resonance Raman bands of the adenine ring and its C8-deuterated analog. J Mol Struct 1998, 447:61-69.

40. Thomas GJ, Hartman KA: Raman studies of nucleic acids. 8. Estimation of RNA secondary structure from Raman scattering by phosphate group vibrations. Biochim Biophys Acta 1973, 312:311-322.

41. Hartman KA, McDonald-Ordzie PE, Kaper JM, Prescott B, Thomas GJJ: Studies of virus structure by laser Raman spectroscopy. 4. Turnip yellow mosaic-virus and capsids. Biochemistry 1978, 17:2118-2123.

42. Nishimura $Y$, Tsuboi M, Nakano T, Higuchi S, Sato T, Shida T, Uesugi S, Ohtsuka E, Ikehara M: Raman diagnosis of nucleic-acid structure - sugarpuckering and glycosidic conformation in the guanosine moiety. Nucleic Acids Res 1983, 11:1579-1588.
43. Hernandez B, Baumruk V, Leulliot N, Gouyette C, Huynh-Dinh T, Ghomi M: Thermodynamic and structural features of ultrastable DNA and RNA hairpins. J Mol Struct 2003, 651:67-74.

44. Razumas V, Niaura G, Talaikyte Z, Vagonis A, Nylander T: Interactions of cyclic AMP and its dibutyryl analogue with model membrane: X-ray diffraction and Raman spectroscopic study using cubic liquid-crystalline phases of monoolein. Biophys Chem 2001, 90:75-87.

45. Daros JA, Flores R: Arabidopsis thaliana has the enzymatic machinery for replicating representative viroid species of the family Pospiviroidae. Proc Natl Acad Sci U S A 2004, 101:6792-6797.

46. Duguid J, Bloomfield VA, Benevides J, Thomas GJ: Raman spectral studies of nucleic acids. 44. Raman spectroscopy of DNA-metal complexes. 1. Interactions and conformational effects of the divalent cations: $\mathrm{Mg}, \mathrm{Ca}$, Sr, Ba, Mn, Co, Ni, Cu, Pd, and Cd. Biophys J 1993, 65:1916-1928.

47. Zhelyaskov V, Yue KT: A Raman study of the binding of Fe(III) to ATP and AMP. Biochem J 1992, 287:561-566.

48. Tatischeff I, Larquet E, Falcón-Pérez JM, Turpin P-Y, Kruglik SG: Fast characterization of cell-derived extracellular vesicles by nanoparticles tracking analysis, cryo-electron microscopy, and Raman tweezers microspectroscopy. J Extracellular Vesicles 2012, 1:19179.

doi:10.1186/2046-1682-7-2

Cite this article as: Hui-Bon-Hoa et al:: Raman characterization of Avocado Sunblotch viroid and its response to external perturbations and self-cleavage. BMC Biophysics 2014 7:2.

\section{Submit your next manuscript to BioMed Central and take full advantage of:}

- Convenient online submission

- Thorough peer review

- No space constraints or color figure charges

- Immediate publication on acceptance

- Inclusion in PubMed, CAS, Scopus and Google Scholar

- Research which is freely available for redistribution

Submit your manuscript at www.biomedcentral.com/submit
C Biomed Central 